Пашинцев В.Г.

\title{
Влияние астрологических знаков на завоевание звания чемпиона олимпийских игр по вольной и греко-римской борьбе
}

Московская государственная академия ветеринарной медицины и биотехнологии имени К.И. Скрябина

(Россия, Москва)

doi 10.18411/spc-04-03-2018-26

idsp 000001:spc-04-03-2018-26

\section{Аннотация}

В статье проведён анализ биографических данных чемпионов олимпийских игр по вольной и греко-римской борьбе (мужчины). Определены знаки Зодиака наиболее благоприятные для этого рода деятельности.

Ключевые слова: знаки зодиака, олимпийские чемпионы, астрологические года, сила воли, храбрость, смелость, интеллект.

Введениедляцеленаправленной подготовки олимпийских чемпионов необходимо использовать и прогноз основанный на исследовании биографических данных уже ставших олимпийскими чемпионами спортсменов. С этой целью был проведён анализ биографических данных олимпийских чемпионов,на влияние астрологических знаков зодиака, на завоевание звания олимпийского чемпиона в вольной и греко-римской борьбе. Всего было проанализировано 331 человек. Анализ астрологических данных по знакам зодиака показал следующее табл. 1.

Наибольший процент олимпийских чемпионов получили рождённые под знаком «Овен» $11,5 \%$, остальные знаки получили от 5,4 до 9,7\% Наименьший процент получил знак «Близнецы» 5,4 \%. Анализ астрологических данных по годам показал, что наиболее благоприятным годом для рождения олимпийских чемпионов, является год «Собаки» 10,9\%.

Знак «Овен» является знаком, который характеризуется очень высоким уровнем храбрости и агрессивности, а также высоким уровнем силы воли, что несомненно позволило спортсменам под этим знаком завоевать звание олимпийского чемпиона.

Олимпийские чемпионы по вольной и греко-римской борьбе по знакам зодиака и

Таблиия 1

астрологическим годам

\begin{tabular}{|c|c|c|c|c|c|c|c|c|c|c|c|c|c|c|}
\hline $\begin{array}{c}\text { Знаки } \\
\text { Зодиака }\end{array}$ & 1 & 2 & 3 & 4 & 5 & 6 & 7 & 8 & 9 & 10 & 11 & 12 & всего & $\%$ \\
\hline Козерог & 1 & 1 & 2 & 3 & 6 & 2 & 0 & 1 & 2 & 2 & 8 & 4 & 32 & 9,7 \\
\hline Водолей & 4 & 5 & 2 & 4 & 0 & 3 & 1 & 2 & 3 & 1 & 2 & 0 & 27 & 8,2 \\
\hline Рыба & 4 & 1 & 4 & 3 & 4 & 3 & 1 & 1 & 4 & 3 & 1 & 1 & 30 & 9,1 \\
\hline Овен & 5 & 4 & 3 & 4 & 2 & 2 & 1 & 5 & 4 & 1 & 4 & 3 & 38 & 11,5 \\
\hline Телец & 2 & 1 & 2 & 3 & 3 & 1 & 2 & 3 & 3 & 1 & 2 & 1 & 24 & 7,3 \\
\hline Близнец & 2 & 2 & 1 & 2 & 1 & 0 & 0 & 2 & 1 & 1 & 3 & 3 & 18 & 5,4 \\
\hline Рак & 1 & 1 & 3 & 0 & 7 & 3 & 1 & 1 & 2 & 0 & 4 & 3 & 26 & 7,9 \\
\hline Лев & 1 & 2 & 2 & 1 & 0 & 5 & 2 & 2 & 3 & 4 & 4 & 3 & 29 & 8,8 \\
\hline Дева & 2 & 5 & 4 & 1 & 1 & 2 & 5 & 6 & 3 & 0 & 2 & 1 & 32 & 9,7 \\
\hline Весы & 4 & 3 & 1 & 1 & 2 & 2 & 3 & 2 & 2 & 4 & 3 & 3 & 30 & 9,1 \\
\hline Скорпион & 4 & 0 & 2 & 3 & 3 & 2 & 1 & 2 & 2 & 2 & 1 & 3 & 25 & 7,6 \\
\hline Стрелец & 1 & 4 & 2 & 2 & 1 & 1 & 1 & 0 & 2 & 2 & 2 & 2 & 20 & 6,0 \\
\hline Итого & 31 & 29 & 28 & 27 & 30 & 26 & 18 & 27 & 31 & 21 & 36 & 27 & 331 & \\
\hline$\%$ & 9,4 & 8,8 & 8,5 & 8,2 & 9,1 & 7,9 & 5,4 & 8,2 & 9,4 & 6,3 & 10,9 & 8,2 & & \\
\hline
\end{tabular}

Примечание: 1-крыса; 2- бык; 3- тигр; 4-кот; 5- дракон; 6- змея; 7-лошадь; 8- коза; 9 - обезьяна; 10 петух; 11- собака; 12- свинья. 
Год «Собаки» характеризуется очень высоким уровнем храбрости, агрессивности и силы воли.что значительно увеличивает шансы рождённых под этим знаком на победу.

Рассмотрение данных по астрологическим стихиям показал табл.2, что наиболее благоприятной является стихия «Земли» которая набрала 26,6\%, за ней следует стихия «Огня» 26,3\%, «Воды» 24,5\% и «Воздуха»22,7\%,

Рассмотрение данных по астрологическим квадратам (крестам) показал табл. 3, что наиболее благоприятным квадратом для рождения смелых, решительных, мужественных людей является Кардинальный крест, который набрала 38,1%, затем следует Постоянный крест 31,7 \% и далее изменчивый крест 30,2\%.

Таблица 2

Распределение Олимпийских чемпионов по астрологическим стихиям

\begin{tabular}{|c|c|c|c|c|}
\hline Показатели & $\begin{array}{c}\text { огня } \\
\text { овен, } \\
\text { лев, } \\
\text { стрелец }\end{array}$ & $\begin{array}{c}\text { воздуха } \\
\text { весы, } \\
\text { водолей, } \\
\text { близнецы }\end{array}$ & $\begin{array}{c}\text { воды } \\
\text { рак, } \\
\text { скорпион, } \\
\text { рыба }\end{array}$ & $\begin{array}{c}\text { земли } \\
\text { козерог, } \\
\text { телец, } \\
\text { дева }\end{array}$ \\
\hline $\begin{array}{c}\text { Олимпийские } \\
\text { чемпионы (331) }\end{array}$ & 87 & 75 & 81 & 88 \\
\hline$\%$ & 26,3 & 22,7 & 24,5 & 26,6 \\
\hline
\end{tabular}

Таблица 3

\section{Распределение Олимпийских чемпионов по астрологическим крестам}

\begin{tabular}{|c|c|c|c|}
\hline Показатели & $\begin{array}{c}\text { Кардинальный } \\
\text { крест } \\
\text { овен, весы, } \\
\text { рак, козерог }\end{array}$ & $\begin{array}{c}\text { Постоянный } \\
\text { крест } \\
\text { телец, скорпион, } \\
\text { водолей, лев }\end{array}$ & $\begin{array}{c}\text { Изменчивый } \\
\text { крест } \\
\text { близнецы, } \\
\text { стрелец, } \\
\text { дева, рыбы }\end{array}$ \\
\hline $\begin{array}{c}\text { Олимпийские } \\
\text { чемпионы (331) }\end{array}$ & 126 & 105 & 100 \\
\hline$\%$ & 38,1 & 31,7 & 30,2 \\
\hline
\end{tabular}

Дважды и более олимпийские чемпионы составляют 14,2\%, наибольшее количество процентов получил знак «Дева» 19,2\%, также большое количество процентов получили Знаки «Весы» 14,9, «Рыбы» 12,8, а также «Телец» 10,4\% табл.4.

Таблий 4

Дважды и более Олимпийские чемпионь по вольной и греко-римской борьбе

\begin{tabular}{|c|c|c|c|c|c|c|c|c|c|c|c|c|c|c|}
\hline $\begin{array}{c}\text { Знаки } \\
\text { Зодиака }\end{array}$ & 1 & 2 & 3 & 4 & 5 & 6 & 7 & 8 & 9 & 10 & 11 & 12 & $\begin{array}{c}\text { всег } \\
\text { о }\end{array}$ & $\%$ \\
\hline Козерог & & & & & & & & 1 & & & & & 1 & 2,1 \\
\hline Водолей & & & & 1 & & 1 & & 1 & & & & & 3 & 6,4 \\
\hline Рыба & 1 & & 1 & 1 & & 1 & 1 & & 1 & & & & 6 & 12,8 \\
\hline Овен & & & 1 & & & & & 1 & & & & 1 & 3 & 6,4 \\
\hline Телец & & & 1 & 1 & 1 & & 1 & & & & 1 & & 5 & 10,4 \\
\hline Близнецы & & & & & 1 & & & & & & & & 1 & 2,1 \\
\hline Рак & & & & & & & & 1 & & & & & 1 & 2,1 \\
\hline Лев & & & & & & & 1 & & & & 1 & 1 & 3 & 6,4 \\
\hline Дева & & 1 & 1 & & 1 & 1 & 1 & 2 & 1 & & & 1 & 9 & 19,2 \\
\hline Весы & 2 & & & & 1 & & 1 & 1 & & 1 & 1 & & 7 & 14,9 \\
\hline Скорпион & 2 & & & & & 1 & & & 1 & & & & 4 & 8,5 \\
\hline Стрелец & & & 1 & 1 & & & & & & & & 2 & 4 & 8,5 \\
\hline Итого & 5 & 1 & 5 & 4 & 4 & 4 & 5 & 7 & 3 & 1 & 3 & 5 & 47 & \\
\hline$\%$ & 10,4 & 2,1 & 4 & 8,5 & 8,5 & 8,5 & 4 & 9 & 6,4 & 2,1 & 6,4 & & & \\
\hline
\end{tabular}

Примечание: 1-крыса; 2- бык; 3- тигр; 4-кот; 5- дракон; 6- змея; 7-лошадь; 8- коза; 9 - обезьяна; 10 петух; 11- собака; 12- свинья. 
Знак «Дева» имеет очень высокие показатели по силе воли и интеллекту, «Телец» и «Рыбы» по силе воли.

Наиболее благоприятными годами рождения для дважды и более олимпийских чемпионов являются года: «Козы» 14,9\%, «Крысы», «Тигра» и «Лошади» по 10,4\%.

Год «Козы» имеет очень высокие показатели по храбрости и силы воли и сильные агрессивные качества. Года «Крысы» очень сильные показатели по храбрости и сильные в агрессивности. Года «Тигра» и «Лошади» имеют сильные показатели в силы воли.

\section{Обсуждение результатов исследования}

Таким образом, в результате проведённого анализа можно отметить, что наиболее благоприятным знаком Зодиака для олимпийских чемпионов по вольной и греко-римской борьбе является «Овен», а годом рождения год «Собаки».

Для выступления в командных соревнованиях наиболее благоприятными являются спортсмены рождённые под знаками «Земли»: «Козерог», «Телец», «Дева».

Для дважды и более олимпийских чемпионов наиболее благоприятный знак Зодиака «Дева» рождённая в года: «Козы», «Крысы», «Тигра» или «Лошади».

$$
* * *
$$

1. Броль Р. В. Астрология как историко-культурный феномен: дис.. канд. культурологии.-М.: МГУКИ, 2001.-236c.

2. Иванов О. Тайны гороскопа судьбы. Влияние планет на нашу жизнь/ О. Иванов.-М.: Амрита,2011.192c.

3. Кива М.М. Астрология и философия/М.М.Кива.-М.: Едиториал УРСС,2003.-184с.

4. Лепёшкин В. Астрология и физкультура // ФиС.-1999.-№11.-С.28-29.

5. Петренко В.В., Бабаев В.Д. Космические законы и судьба человека. Астрология. Астрономия/В.В. Петренко, В.Д. Бабаев.- М.: Амрита, 2012.- 272 с.

6. Платон Влияют ли на нас звезды // Человек.-2004.-№ 3.-С.118-131.

7. Русланов Д.В. Астрологические и нумерологические аспекты выбора профессии// Физическое воспитание студентов творческих профессий: ХГАДИ: Харьков, 2001.-№5.-С.49-52.

8. Спиридонов Е.А. Физиоментальный подход в процессе обучения и реабилитации в спорте.// Спортивный психолог: № 3.-2007.-С. 33-39.

9. Шевченко В.В. Человек зодиака// Человек.-2004.-№2.-С.54-66.

\section{Пономарева Е.А. \\ Психологические аспекты практического менеджмента в образовательных учреждениях}

Московский городской педагогический университет (Россия, Москва)

doi 10.18411/spc-04-03-2018-27

idsp 000001:spc-04-03-2018-27

В современных условиях активизируются процессы реорганизации в образовательных системах; актуальными становятся проблемы разработки инновационных подходов в обучении, воспитании и развитии учащихся, а также формирования и поддержания позитивного имиджа педагогических организаций, овладения новыми технологиями образовательного менеджмента, включая прикладные социально-психологические методы. Совершенствование образования во многом зависит от состояния управления и менеджмента в образовательных учреждениях [2].

Стратегически внутришкольный менеджмент направлен на обеспечение оптимального режима деятельности как образовательной системы в целом, так и ее основных подсистем (в частности педагогической, кадровой, психологической). Социально-психологическая составляющая в процессе руководства деятельностью сотрудников должна, в свою очередь, обеспечивать эффективность и качество результатов педагогического труда всего коллектива организации $[1 ; 4]$. 